Research Article

\title{
Effects of acupressure therapy period towards blood sugar level in type 2 diabetes mellitus patients at Lumajang acupressure clinic
}

Anung Putri Illahika ${ }^{1 *}$, Hean Safira ${ }^{2}$

1,2) Faculty of Medicine University of Muhammadiyah Malang, East Java, Indonesia

\begin{tabular}{ll}
\multicolumn{2}{c}{ A R T I C L E I N F O } \\
\hline Submitted & : June 2020 \\
Accepted & : October 2020 \\
Published & : January 2021 \\
\hline
\end{tabular}

\section{Keywords:}

Acupressure, the period of therapy, blood glucose level, type two diabetes mellitus

\section{*Correspondence:}

Anungputri113@gmail.com

\begin{abstract}
Diabetes Mellitus is a worldwide metabolic disease and becomes a challenge for the health practitioner. Unfortunately, less than half of these diabetic individuals are aware of their conditions, and less than $1 \%$ of those receiving medical treatment achieve their therapeutic targets. Acupressure is an alternative method that is believed to be an effective way of treating diabetic patients with reducing symptoms and complications. This research aims to discover the effect of period acupressure therapy on blood sugar levels in type two diabetes mellitus patients in Lumajang Acupressure Clinic. It uses an observational analytic design with pre-test and post-test approach. It involved 36 participants who were split into two groups and contained 18 participants for each group. The first group received acupressure therapy for three weeks, while the second group received eight weeks. Both groups underwent acupressure at the San Yin Jiao (SP-6) acupoint for 20 minutes three times a week. All participants in both groups had their blood glucose checked before and after acupressure therapy. The results showed that the two groups were significantly different for the paired t-test and the independent t-test. The acupressure therapy period has an effect on decreasing blood sugar levels in type two diabetes mellitus patients at Lumajang acupressure clinic.
\end{abstract}




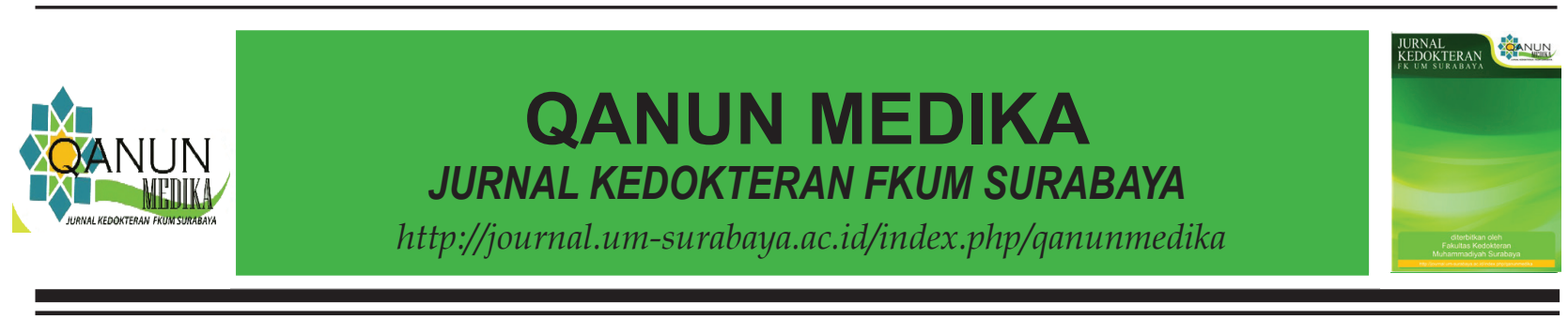

\section{INTRODUCTION}

Diabetes mellitus is defined as the chronic failure of the metabolism function in the human body as a result of insulin deficiency. Diabetes mellitus is a worldwide metabolic disease and becomes a challenge for health practitioners (Azitha et al., 2018). According to the International Diabetes Federation, around 425 million adults are affected by diabetes and are expected to increase to 629 million by 2045 (World Health Organization, 2016). Indonesia has 10 million diabetic and 17,9 million prediabetic citizens. It is predicted that Indonesia will rank among the top 5 countries with diabetes mellitus in the world in 2030 (Rachmayanti et al., 2017). When not managed properly, all types of diabetes can lead to complications that affect many parts of the body, even death. The severity of symptoms is due to the type and duration of diabetes (Kharroubi, 2015). Most diabetics are in developing countries. Since 2014 Asia and Africa have the highest number of diabetes (Fitrullah \& Rousdy, 2017).

The prevalence of Type 2 diabetes mellitus (T2DM) is more common than Type 1 diabetes mellitus or gestational diabetes. The prevalence of $\mathrm{T} 2 \mathrm{DM}$ is $30-50 \%$, while gestational diabetes is $10-25 \%$, and the rest is DM Type 1 . The proportion of T2DM cases reaches $57 \%$ of all cases of diabetes mellitus in all hospitals in East Java (Dinkes Jawa Timur, 2018). The classic diabetes symptoms such as polyuria, polydipsia, and polyphagia occur commonly in type 1 diabetes, which has a rapid development of severe hyperglycemia and type 2 diabetes with very high levels of hyperglycemia (Ramachandran, 2014). One helpful indicator of T2DM disease is high blood sugar levels. The disease can also cause neuropathy complications, which results in losing the sense of taste and increased pain in the affected part. The most common complaint is tingling. The more various complaints in patients with T2DM, the risk of complications also increases (Meidikayanti \& Wahyuni, 2017).

Unfortunately, less than half of these diabetic individuals are aware of their conditions, and less than $1 \%$ of those receiving medical treatment achieve their healing targets. One of the main factors is that they were not comfortable with medication and even used alternative medicine to cure their illness. T2DM patients tend to seek alternative therapies to reduce their blood sugar levels. Up to $64 \%$ of T2DM patients who use Complementary and Alternative Medicine $(C A M)$ or alternative therapies use it to control blood sugar levels (Naja et al., 2017).

The United States National Center for Complementary and Alternative Medicine (NCCAM) introduces alternative therapies as a medical system and health care products and practices that are not currently considered routine medical care. Alternative therapies consist of various practices such as massage therapy, music therapy, hypnotherapy, laughter therapy, acupuncture, and acupressure (Fogarty et al., 2016).

Acupressure, a method derived from Traditional Chinese Medicine (TCM), is an alternative medical therapy by applying certain pressure using a finger, thumb, or an instrument to an acupoint in the human body. Acupressure is gaining attention in the near future. The benefits of acupressure therapy are practical, effective, and safe (Zick et al., 2016). Acupressure is an effective method for reducing blood sugar levels and helping to minimize complications in diabetic patients (Fitrullah \& Rousdy, 2017). From the description above, this study aims to find out the effectiveness of acupressure therapy to reduce blood sugar levels in T2DM patients if acupressure is conducted with different time periods considering that diabetes patient continues to increase and it is difficult to find a comfortable and appropriate therapy. 


\section{METHODS}

The design in this study was quantitative with an observational analytic design and a pretest and post-test approach. There were two groups in this study; the first group underwent therapy for three weeks, and the second group for eight weeks. This study was conducted in Lumajang Acupressure Clinic in November 2019 for approximately eight weeks. This study population was all T2DM patients in Lumajang Acupressure Clinic, while the sample was T2DM patients who match the inclusion criteria. The sampling technique was consecutive sampling, which was part of nonprobability sampling and was the best type of sampling in clinical studies (Sugiyono, 2008).

The inclusion criteria were patients aged $>18$ years, T2DM patients (proven by the results of laboratory examinations), patients who took pre-test data in $\leq 3$ weeks of visits, patients who took pre-test data in $\leq 8$ weeks of visits, patients who came for the first visit and brought the results of the laboratory examination, patients who have been receiving OHA therapy, and willing to follow research. The exclusion criteria were patients who did not complete therapy until the 3rd weeks of visit (group 3 weeks) and the 8 th weeks of visit ( 8 weeks group), Pregnant women during the study, T2DM patients with complications, not willing to follow the research, their condition worsens so that they can not continue research and die.

The independent variable in this study was the period of acupressure therapy, while the dependent variable was blood sugar levels. The instruments that we used were a questionnaire sheet and blood sugar measuring device Easy Touch GU 'Acrilyc' to measure blood sugar levels. The questionnaire consists of 7 questions: name, age, sex, frequency of exercise, OHA therapy, previous acupressure therapy, and history of suffering Diabetes Mellitus. These tools had been tested for validity before use. When pressing the start button, it displays stip lights up on the screen, meaning the device works correctly and valid if the display on the screen is an error sign indicating there is a problem with the device or invalid, so it requires repair or replacing the battery.

The data were analyzed using univariate analysis and bivariate analysis. Univariate analysis was performed to describe each variable. Univariate analysis was about respondents' characteristics, including age, sex, frequency of exercise, OHA therapy, description of previous acupressure therapy, history of T2DM, and average values of blood sugar levels before and after acupressure therapy. Bivariate analysis in this study using unpaired t-test and paired t-test.

\section{RESULTS}

Table 1 shows the frequency distribution for 36 patients with type 2 diabetes mellitus in Lumajang Acupressure Clinic.

From Table 2, there were differences in average pre-test blood sugar levels between each treatment group. The 8-week therapy group had a higher rate than the 3 -week therapy group. The post-test data in the 3-week therapy group had a higher rate than the 8-week therapy group.

The result of the paired t-test (Table 3) was $p<0.05$, which means that each treatment group presented significant differences. The mean difference in the 3-week therapy group was 45.22 , while the 8 -week therapy group was 83.17. The 8-week therapy group had a more significant difference than a 3-week therapy group. A normality test for difference data was performed and obtained a sig $>0.05$, which indicates that the data was normally distributed. 
Table 1. Demographic Characteristics of Type 2 Diabetes Mellitus Patients in Lumajang Acupressure Clinic

\begin{tabular}{lccc}
\hline \multicolumn{1}{c}{ Variable } & $\begin{array}{c}\text { 3 weeks } \\
\mathrm{f}(\%)\end{array}$ & $\begin{array}{c}\mathbf{8} \text { weeks } \\
\mathrm{f}(\%)\end{array}$ & $\begin{array}{c}\text { Total (\%) } \\
\mathrm{f}(\%)\end{array}$ \\
$\begin{array}{l}\text { Age } \\
<45 \text { years }\end{array}$ & $11(61)$ & $9(50)$ & $20(56)$ \\
$\quad>45$ Years & $7(39)$ & $9(50)$ & $16(44)$ \\
Gender & & & \\
$\quad$ Men & $11(61)$ & $8(45)$ & $19(53)$ \\
$\quad$ Women & $7(39)$ & $10(55)$ & $17(47)$ \\
Sports Routine & & & \\
$\quad$ Already & $11(61)$ & $13(72)$ & $24(67)$ \\
$\quad$ Not already & $7(39)$ & $5(28)$ & $12(33)$ \\
Complying with Diet & & & \\
Already & $12(67)$ & $16(89)$ & $28(78)$ \\
$\quad$ Not already & $6(33)$ & $2(11)$ & $8(12)$ \\
Old Suffering DMT2 & & & \\
$\quad<1$ Year & $3(17)$ & $2(13)$ & $5(14)$ \\
$>1$ Year & $15(83)$ & $16(87)$ & $31(86)$ \\
\hline
\end{tabular}

Table 2. Average Blood Sugar Levels (mean \pm SD) Before and After Acupressure Therapy

\begin{tabular}{cccc}
\hline \multirow{2}{*}{ Blood sugar levels } & \multirow{2}{*}{$\mathbf{N}$} & \multicolumn{2}{c}{ Group } \\
\cline { 3 - 4 } & & 3 weeks & 8 weeks \\
\hline Pre-test & 18 & $245,72 \pm(53,672)$ & $278 \pm(55,89)$ \\
Post test & 18 & $200,50 \pm(53,672)$ & $194,83 \pm(33,064)$ \\
\hline
\end{tabular}

Table 3. Paired T-test Results

\begin{tabular}{|c|c|c|c|c|}
\hline \multirow{2}{*}{ Group } & \multicolumn{2}{|c|}{ Blood sugar level $($ mean \pm SD) } & \multirow{2}{*}{$\begin{array}{l}\text { Average } \\
\text { difference }\end{array}$} & \multirow{2}{*}{ P-Value } \\
\hline & Pre-test & Post-test & & \\
\hline 3 weeks & $245,72 \pm 53,672$ & $200,50 \pm 53,672$ & 45,22 & $0,000 *$ \\
\hline 8 weeks & $278,00 \pm 55,890$ & $194,83 \pm 33,064$ & 83,17 & $0,000 *$ \\
\hline
\end{tabular}

*significant

Table 4. Unpaired T-test Results

\begin{tabular}{lccc}
\hline & \multicolumn{2}{c}{ Group } & \multirow{2}{*}{ P-Value } \\
\cline { 2 - 3 } Average difference & 3 weeks & $\mathbf{8}$ weeks & \\
\cline { 2 - 4 } & 45,22 & 83,17 & $0,036^{*}$ \\
\hline
\end{tabular}

*significant 
Furthermore, to determine the more effective period of therapy, an unpaired t-test was run on different average data. Before that normality test was conducted first, and the result was p $>0.05$ means the data has been normally distributed (attachment). In table 4, p <0.05 $(p=0.036)$ is obtained, which means there is a significant difference between the average difference in blood sugar levels in 3-week and 8 -week treatment groups.

\section{DISCUSSION}

This study was conducted on 36 respondents. Characteristics of respondents, including sex, age, regular exercise, duration of suffering from T2DM, and adherence to the diet, analyzed descriptively. Based on table 1, T2DM patients at Lumajang Acupressure Clinic were dominantly men, which was contradicted with research that there were more women with T2DM than men respondents because women perceived more stress that can affect an increase in blood sugar levels (Lisanawati et al., 2015). However, the results were in line with Nordstrom that comprised 1393 participants, and type 2 diabetes prevalence was higher in men than in women (Nordström et al., 2016).

In this study, respondents were dominated by age $<40$ years. This result was in line with Ha's that stated there was a significant increase in the percentage of patients that were newly diagnosed with diabetes at the age of $\leq 40$ years (Ha et al., 2018). However, it was contradicted with a study conducted by $\mathrm{Xu}$ that stated the percentage of type 2 diabetes was higher among older adults (age $\geq 65$ years) (Xu et al., 2018). Respondents in this study also dominated by those who did routine exercise, so this outcome was reciprocal with Kosim's research that out of the 40 samples used, $80 \%$ of them were T2DM patients who gained routine exercise recommendations as non-pharmacological therapy in T2DM (Kosim et al., 2017). Respondents of this study were dominated by those who were adhered to diet recommendations, which contradicted research that stated that $56 \%$ of them did not adhere to diet recommendations (Risnasari, 2014).

There was an effect on blood sugar levels after acupressure therapy. Data exhibited acupressure therapy can reduce blood sugar levels in both groups. This was in line with research that involved 60 respondents using ST-36, LIV-3, KD-3, and SP-6 acupoint for 20 minutes ( 5 minutes per acupoint) for 3 weeks. The study utilized fasting blood sugar as a dependent variable obtaining that acupressure can significantly reduce blood sugar levels and reduce complications in T2DM patients (Zarvasi et al., 2018). This study's results are also in line with research that exerted 30 respondents and acupoint ST36 for 30 minutes within 8 weeks; the indicator was random blood sugar levels obtaining that acupressure can reduce blood sugar levels and reduce complications in T2DM patients significantly (Fitrullah \& Rousdy, 2017). The mechanism contributed to these results was that acupressure could stimulate the secretion of neurotransmitters that regulate endocrine glands (pancreas) through the transmission of the nervous system and reduce blood sugar levels through the effects of relaxation and stress reduction (Zarvasi et al., 2018). In addition, the action mechanism of acupressure can also through mRNA expression pathways from GLUT2 and GCK to reduce levels of FINS and protect the morphology of pancreatic beta cells (Feng et al., 2018).

The 8-weeks therapy group had a greater average difference than the 3-weeks group (Table 4). Acupressure therapy can reduce blood sugar levels through the mechanism of nerve excitation, mRNA expression, and NO synthesis (Feng et al., 2018). If continuously occur, these three mechanisms will help reduce the production of free fatty acids, increase glucose transport into cells, and improve the 


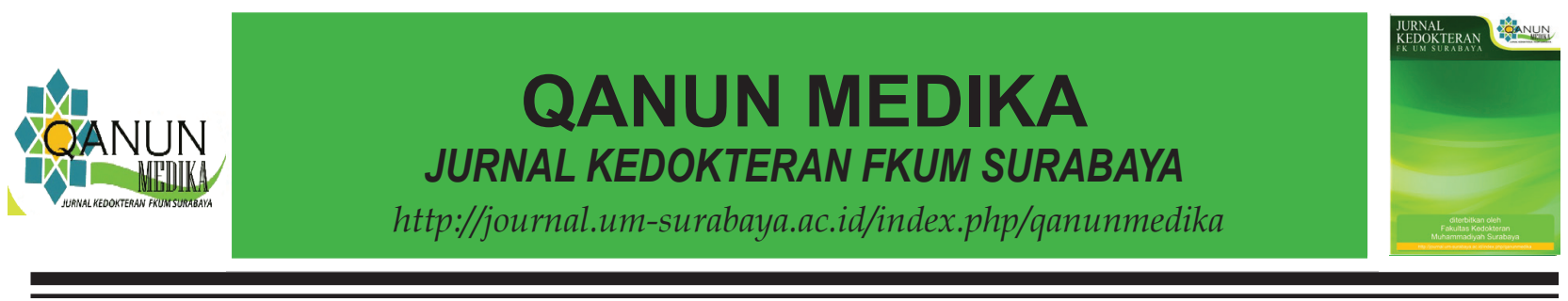

morphology of pancreatic beta cells, thereby reducing insulin resistance and blood sugar levels in T2DM patients. Unpaired t-test presented a significant difference between the mean difference of blood sugar levels in the 3-weeks acupressure group and 8-weeks acupressure group. The longer acupressure therapy is carried out, the effect will get better, wherein this study, the intended effect was decreased random blood sugar levels. The acupressure therapy with 8 weeks period of therapy is more effective than 3 weeks because it can reduce blood sugar levels more. There was a significant effect of acupressure therapy on blood sugar levels in T2DM patients. However, the decrease in blood sugar levels in this study was not only caused by acupressure, because the mechanism of insulin resistance and regulation of blood sugar levels is not a stand-alone mechanism but depends on the intervention given, the acupoint, target population, and lifestyle of the respondents.

\section{CONCLUSION}

The period of acupressure therapy has an effect on decreasing blood sugar levels in type two diabetes mellitus patients at Lumajang acupressure clinic.

\section{REFERENCES}

Azitha, M., Aprilia, D., \& Ilhami, Y. R. (2018). Hubungan Aktivitas Fisik dengan Kadar Glukosa Darah Puasa pada Pasien Diabetes Melitus yang Datang ke Poli Klinik Penyakit Dalam Rumah Sakit M. Djamil Padang. Jurnal Kesehatan Andalas, 7(3), 400. https:// doi.org/10.25077/jka.v7i3.893

Dinkes Jawa Timur. (2018). Hasil Utama Riset Kesehatan Dasar Jawa Timur 2018. In Jakarta: Badan Penelitian dan Pengembangan Kesehatan, Kementrian Kesehatan Republik Indonesia.
Feng, Y., Fang, Y., Wang, Y., \& Hao, Y. (2018). Acupoint Therapy on Diabetes Mellitus and Its Common Chronic Complications: A Review of Its Mechanisms. BioMed Research International, 2018, 1-9. https:// doi.org/10.1155/2018/3128378

Fitrullah, \& Rousdy, A. (2017). Effectiveness of Acupressure at the Zusanli (ST-36) Acupoint as a Comfortable Treatment for Diabetes Mellitus: A Pilot Study in Indonesia. JAMS Journal of Acupuncture and Meridian Studies, 10(2), 96-103. https://doi.org/10.1016/j. jams.2016.12.003

Fogarty, S., Smith, C. A., \& Hay, P. (2016). The role of complementary and alternative medicine in the treatment of eating disorders: A systematic review. Eating Behaviors, 21, 179-188. https://doi. org/10.1016/j.eatbeh.2016.03.002

Ha, K. H., Kim, D. J., \& Kim, S. (2018). Clinical characteristics of people with newly diagnosed type 2 diabetes between 2015 and 2016: Difference by age and body mass index (Diabetes Metab J 2018;42:13746). Diabetes and Metabolism Journal, 42(3), 251-253. https://doi.org/10.4093/ dmj.2018.0099

Kharroubi, A. T. (2015). Diabetes mellitus: The epidemic of the century. World Journal of Diabetes, 6(6), 850. https://doi. org/10.4239/wjd.v6.i6.850

Kosim, M. N., Damayanti, S., \& Sucipto, A. (2017). Hubungan Dukungan Sosial Keluarga Dengan Kepatuhan Olahraga Pasien Diabetes Melitus Tipe 2 Di Kelompok Persadia Rs Pku Muhammadiyah Yogyakarta. Universitas Respati Yogyakarta, 12(2), 1-9. https://doi. org/https://doi.org/10.35842/mr.v0i0.86 
Lisanawati, R., Hasneli, Y., \& Hasanah, O. (2015). Perbedaan Sensitivitas Tangan Dan Kaki Sebelum Dan Sesudah Dilakukan Terapi Pijat Refleksi Pada Penderita Diabetes Melitus Tipe II. JOM, 2(37), 1402-1409. https://doi. org/10.12816/0013114

Meidikayanti, W., \& Wahyuni, C. U. (2017). Hubungan dukungan keluarga dengan kualitas hidup Diabetes Melitus Tipe 2 Di Puskesmas Pademawu. Jurnal Berkala Epidemiologi, 5(2), 240-252. https://doi. org/10.20473/jbe.v5i2.2017.240-252

Naja, F., Anouti, B., Shatila, H., Akel, R., Haibe, Y., \& Tfayli, A. (2017). Prevalence and Correlates of Complementary and Alternative Medicine Use among Patients with Lung Cancer: A Cross-Sectional Study in Beirut, Lebanon. EvidenceBased Complementary and Alternative Medicine, 2017, 1-11. https://doi. org/10.1155/2017/8434697

Nordström, A., Hadrévi, J., Olsson, T., Franks, P. W., \& Nordström, P. (2016). Higher prevalence of type 2 diabetes in men than in women is associated with differences in visceral fat mass. Journal of Clinical Endocrinology and Metabolism, 101(10), 3740-3746. https://doi.org/10.1210/ jc.2016-1915

Rachmayanti, A. A., Murbawani, E. A., \& Wijayanti, H. S. (2017). Hubungan Asupan Niasin Dengan Kadar Glukosa Darah Puasa Pada Wanita 30-55 Tahun Di Kota Semarang. Journal of Nutrition College, Volume 6, Nomor 3, 184(4681), 227-233. https://doi.org/10.1038/184156a0

Ramachandran, A. (2014). Know the sign and symptoms of diabetes. Indian Journal of Medical Research, 140(5), 579-581. https://www.ncbi.nlm.nih.gov/pmc/ articles/PMC4311308/?report=printable
Risnasari, N. (2014). Hubungan Tingkat Kepatuhan Diet Pasien Diabetes Mellitus dengan Munculnya Komplikasi di Puskesmes Pesantren IIKota Kediri. Efektor, 01(25), 15-19.

Sugiyono. (2008). Metode penelitian pendidikan:(pendekatan kuantitatif, kualitatif dan $R \& D$ ). Alfabeta.

World Health Organization. (2016). World Health Day 2016: WHO calls for global action to halt rise in and improve care for peoplewith diabetes. WHO. https://www. who.int/diabetes/global-report/WHD16press-release-EN_3.pdf?ua $=1$

Xu, G., Liu, B., Sun, Y., Du, Y., Snetselaar, L. G., Hu, F. B., \& Bao, W. (2018). Prevalence of diagnosed type 1 and type 2 diabetes among US adults in 2016 and 2017: Population based study. BMJ (Online), 362. https://doi.org/10.1136/ bmj.k1497

Zarvasi, A., Ansari Jaberi, A., Negahban Bonabi, T., \& Tashakori, M. (2018). Effect of self-acupressure on fasting blood sugar (FBS) and insulin level in type 2 diabetes patients: a randomized clinical trial. Electronic Physician, 10(8), 7155-7163. https://doi.org/10.19082/7155

Zick, S. M., Sen, A., Wyatt, G. K., Murphy, S. L., Todd Arnedt, J., \& Harris, R. E. (2016). Investigation of 2 types of selfAdministered acupressure for persistent cancer-related fatigue in breast cancer survivorsarandomized clinical trial.JAMA Oncology, 2(11), 1470-1476. https://doi. org/10.1001/jamaoncol.2016.1867 